日本結晶学会誌35,209(1993)

〔最近の研究から〕

\title{
$A \mathrm{~V}_{6} \mathrm{O}_{11}(A=\mathrm{Na}, \mathrm{Sr})$ の結晶構造と磁性
}

無機材質研究所 菅家 康

Yasushi KANKE : Crystal Structures and Magnetic Properties of $A \mathrm{~V}_{6} \mathrm{O}_{11}(A=\mathrm{Na}, \mathrm{Sr})$.

New phases which contain mixed-valent vanadium; $\operatorname{SrV}_{6} \mathrm{O}_{11}, \operatorname{Sr} T_{x} \mathrm{~V}_{6-x} \mathrm{O}_{11}(T=\mathrm{Ti}, \mathrm{Cr}, \mathrm{Fe})$ and $\mathrm{NaFe}_{3} \mathrm{~V}_{9} \mathrm{O}_{19}$ were synthesized. Crystal structures of them and $\mathrm{NaV}_{6} \mathrm{O}_{11}$ were determined and discussed in comparison with the magnetoplumbite structure. Random cation distributions in $\operatorname{Sr} T_{x} \mathrm{~V}_{6-x} \mathrm{O}_{11}$ suggest that $A T_{6} \mathrm{O}_{11}$ phases contain itinerant d-electrons. $\mathrm{NaV}_{6} \mathrm{O}_{11}, \mathrm{SrV}_{6} \mathrm{O}_{11}$ and $\mathrm{NaFe}_{3} \mathrm{~V}_{9} \mathrm{O}_{19}$ were revealed to show spontaneous magnetization.

\section{1.はじめに}

第一長周期元素酸化物の電気伝導性を決める要 因は, 3d電子が個々の遷移金属イオンに局在する のか金属イオン間を自由に動きまわれるのが, $\mathrm{O}^{2-}$ から遷移金属イオンへの電子移動が可能か否 か2), の2つが主とされている。前者は3d電子間の クーロン反発に, 後者は遷移金属元素と酸素との 電気陰性度の差に依存すると言われている。従来 の研究では, 第一長周期元素のうち前半の酸化物 では, クーロン反発は比較的弱く $3 \mathrm{~d}$ 電子は局在と 非局在との境目にある一方, 電気陰性度の差は比 較的大きく $\mathrm{O}^{2-}$ から遷移金属イオンへの電子移動は 不可能とされ, 後半の酸化物では, その逆の関係 にあると考えられている。3価 4価領域のバナジ ウム酸化物には, $\mathrm{V}_{2} \mathrm{O}_{3}$, マグネリ相, $\mathrm{V}_{2} \mathrm{O}_{4}$ 等, 固 有の温度で金属一絶緣体転移を示すものが多く, その3d電子は局在と非局在との境目にあるとされ ている。バナジウム酸化物は, $3 \mathrm{~d}$ 電子の局在非局 在性の関わる物性を研究する格好の対象と言え る。

結晶化学の立場からバナジウム酸化物をみる と, 多様な結晶構造が注目される。この要因とし て, バナジウムは 2 価から5価までの幅広い酸化数 をとること，酸化数ごとに多様なイオン半径およ び配位様式をもつことが考えられる。バナジウム 酸化物は, 遷移金属の酸化数および $3 \mathrm{~d}$ 電子数と結
晶構造との関係を研究する上でも格好の対象と言 える。

\section{2. $A \mathrm{~V}_{6} \mathrm{O}_{11}(A=\mathrm{Na}, \mathrm{Sr})$ の結晶構造と磁性}

最近, $\mathrm{NaV}^{\mathrm{IV}}{ }_{3} \mathrm{~V}^{\mathrm{III}}{ }_{3} \mathrm{O}_{11}$ (六方晶系, $\mathrm{P} \overline{6} 2 \mathrm{c}$ )が見いた された ${ }^{3)}$ 。同じ $\mathrm{V}^{\mathrm{III}}-\mathrm{V}^{\mathrm{IV}}$ 混合原子価領域にあるマグ ネリ相, $\mathrm{LiV}^{\mathrm{III}} \mathrm{V}^{\mathrm{IV}} \mathrm{O}_{4}$ (正スピネル)とは全く異なる結 晶構造をもつ。 $\mathrm{V}^{\mathrm{IV}}-\mathrm{V}^{\mathrm{V}}$ 領域に比べ， $\mathrm{V}^{\mathrm{III}}-\mathrm{V}^{\mathrm{IV}}$ 領域 の既知相は非常に少ないことを考えると, $\mathrm{NaV}_{6} \mathrm{O}_{11}$ の存在は重要であり, その電気的磁気的性質の解 明は意義深い。 $\mathrm{NaV}_{3}^{\mathrm{IV}}{ }_{3} \mathrm{~V}_{3}^{\mathrm{III}} \mathrm{O}_{11}$ は3 種のVサイトを 持つが， VIII と $\mathrm{V}^{\mathrm{IV}}$ は各々特定のサイトに片寄った 分布をとるのか否か, $\mathrm{Na}^{+}$が2価, 3価のカチオン に変わり, $\mathrm{V}^{\mathrm{III}} / \mathrm{V}^{\mathrm{IV}}$ 比が変わった場合に同型の相は 存在するのか, 存在するならば $\mathrm{V}^{\mathrm{III}}$ と $\mathrm{V}^{\mathrm{IV}}$ の分布は どのように変わるのか, $3 \mathrm{~d}$ 電子の局在非局在の観 点から興味深い。以上を踏まえ, $A \mathrm{~V}_{6} \mathrm{O}_{11}$ 相 $(A$ は2 価または3価のカチオン)の探索を試みた。また, 単結晶試料を用いて $\mathrm{NaV}_{6} \mathrm{O}_{11}$ の電気的磁気的性質 を調べた。

\section{1 合 成}

真空封入法を用いた固相反応により, $A \mathrm{~V}_{6} \mathrm{O}_{11}(A$ $=\mathrm{Ca}, \mathrm{Sr}, \mathrm{Ba}, \mathrm{La}, \mathrm{Nd})$ の合成を試みた。 $A=\mathrm{Sr}$ に限 り成功し, 1473 1673K の温度で $\operatorname{SrV}_{6} \mathrm{O}_{11}$ の粉末お よび単結晶試料が得られた ${ }^{4), 5) 。 ~}$

$\mathrm{NaV}_{6} \mathrm{O}_{11}$ は $\mathrm{NaVO}_{3}$ 融液の電解還元により見いだ されだ)が, 上記の固相反応法で 923 993Kの加熱 
温度により合成できることがわかった6)。その単結 晶試料は2段階の加熱手順で得られた ${ }^{5), 6) 。 ~}$

\section{2 単結晶X線楼造解析}

$\mathrm{AV}_{6} \mathrm{O}_{11}$ は $\mathrm{BaTi}_{2} \mathrm{Fe}_{4} \mathrm{O}_{11}{ }^{7}$ ), $\mathrm{BaSn}_{2} \mathrm{Fe}_{4} \mathrm{O}_{11}{ }^{7}$ (六方晶
系, $\left.\mathrm{P}_{3} / \mathrm{mmc}\right)$ と同型であり, マグネトプランバイ 卜型 $\mathrm{BaFe}_{12} \mathrm{O}_{19}{ }^{8}$ (六方晶系, $\mathrm{P}_{3} / \mathrm{mmc}$ ) と結晶構造が 関連することが判明した (第 1 図)。 $\mathrm{BaFe}_{12} \mathrm{O}_{19}$ はス ピネルブロック (S)と Rブロックから成り，[001]方。

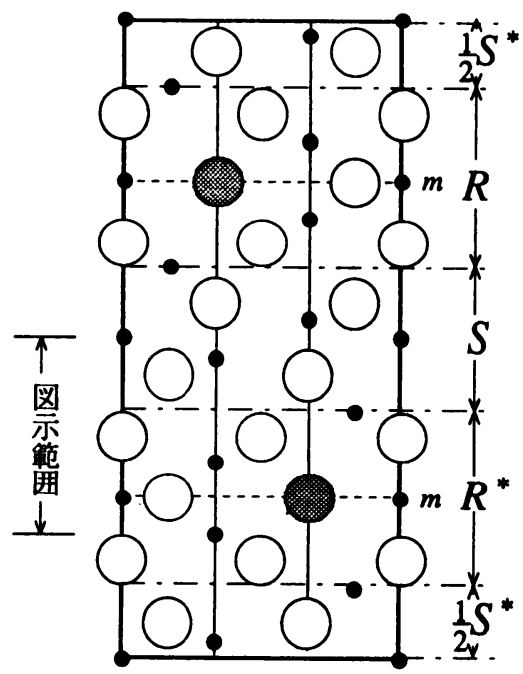

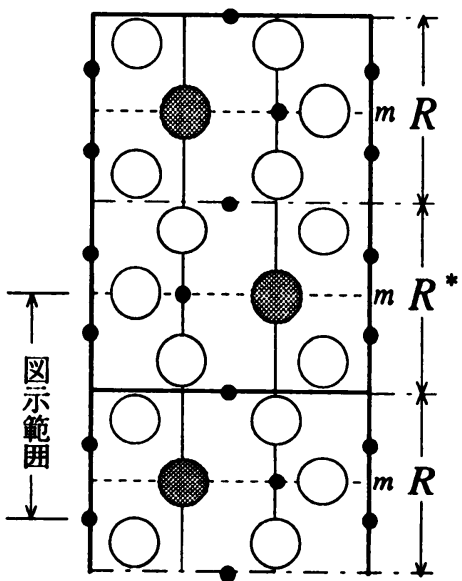

$A T_{6} \mathrm{O}_{11}$

\section{$\mathrm{BaFe}_{12} \mathrm{O}_{19} \quad$ (110)断面図}

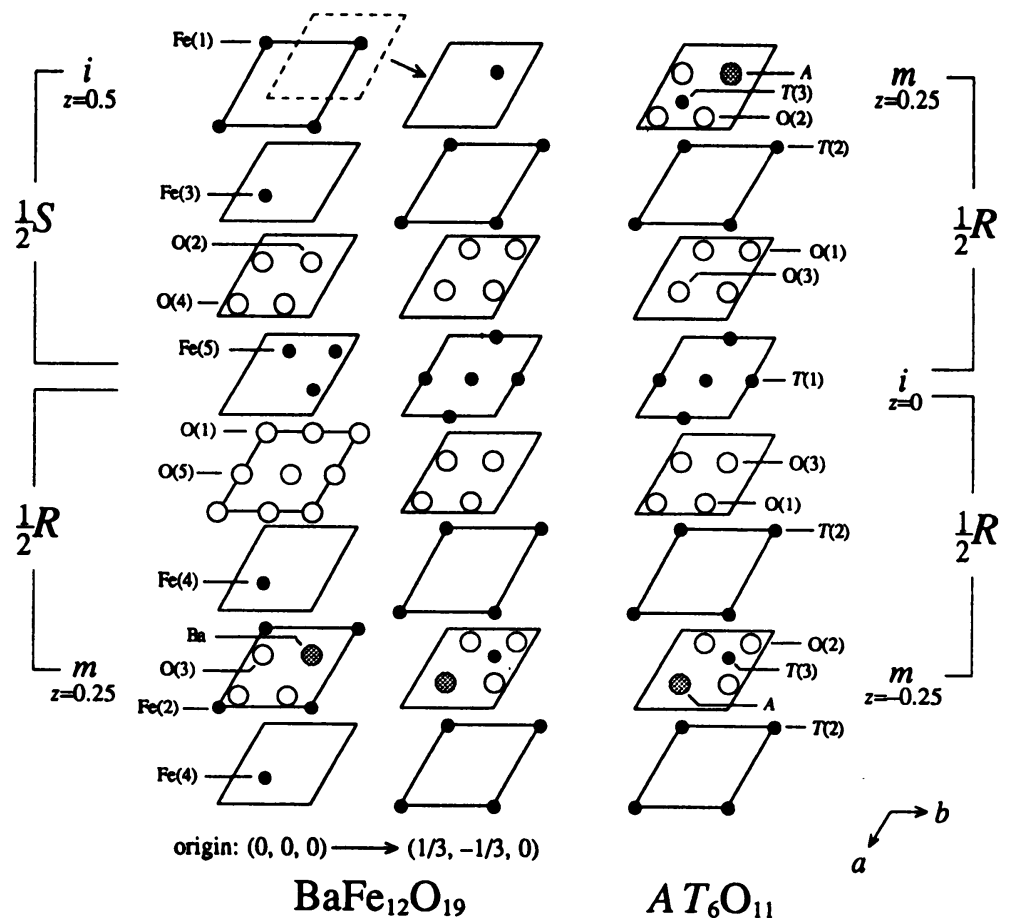

層状構造としての比較

第1図 $\mathrm{BaFe}_{12} \mathrm{O}_{19}$ と $A T_{6} \mathrm{O}_{11}$ 型化合物 (共に六方晶系, $\mathrm{P} 6_{3} / \mathrm{mmc}$ ) との 結晶構造の比較4) 
向に沿った配列順序は単位格子あたり RSRS であ る。 $A T_{6} \mathrm{O}_{11}$ 型化合物は $\mathrm{R}$ ブロックのみから成り， 対応する配列順序はRRである。 $A T_{6} \mathrm{O}_{11}$ において， $T(1) 八$ 面体は $[001]$ に垂直な面内で稯共有で網目状 の層を成す。 $T(2)$ 八面体は $[001]$ に垂直な鏡面 $(z=$ $1 / 4,3 / 4)$ を挟んで同じ $T(2) 八$ 面体と隣接し, 面共有 の二量体を成す。 $T(3)$ サイトは，理想的にはその 鏡面上にあり, 三方両錐型5配位をとる。しかし， $\mathrm{BaTi}_{2} \mathrm{Fe}_{4} \mathrm{O}_{11}, \mathrm{BaSn}_{2} \mathrm{Fe}_{4} \mathrm{O}_{11}$ のT(3)サイトは[001]方向 に変位して1組の歪んだ四面体型サイトとなり，力 チオンはその片方を無秩序に占めている7)。

$\mathrm{BaFe}_{12} \mathrm{O}_{19}$ でも, 対応する $\mathrm{Fe}(2)$ サイトには同様の変 位がある8)。 $A T_{6} \mathrm{O}_{11}$ のT(1), $T(2), T(3)$ の各サイト 数の比率は $3: 2: 1$ である。

De Roy $ら^{3}$ ) は, 可能性のある3 種の空間群 $\mathrm{P}_{3} /$ mmc, $\mathrm{P} \overline{6} 2 \mathrm{c}, \mathrm{P} 6 \mathrm{z} \mathrm{mc}$ のうち, $\mathrm{P} \overline{6} 2 \mathrm{c}$ のみが適切な $\mathrm{Na}-$ $\mathrm{O}$ 距離を与えたとして, 対称心を欠く $\mathrm{P} \overline{6} 2 \mathrm{c}$ を $\mathrm{NaV}_{6} \mathrm{O}_{11}$ の空間群に選んだ。彼らはさらにR值が下

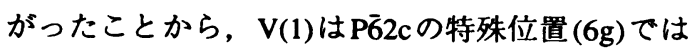
なく占有率1/2で一般位置(12i)にあると結論した。

我々も彼らと同じ $\mathrm{MoK} \alpha$ 線を用いて, $\mathrm{NaV}_{6} \mathrm{O}_{11}$, $\mathrm{SrV}_{6} \mathrm{O}_{11}$ の単結晶の回折強度を測定した。 $\mathrm{P} 6 \overline{2} \mathrm{c}$, $\mathrm{P} 6_{3} \mathrm{mc}$ からは各2種の構造モテルが導かれる。
$\mathrm{NaV}_{6} \mathrm{O}_{11}$ の空間群を以下の手順で検討した。構造パ ラメータを精密化した後, モテルごとに $\left|F_{\mathrm{C}}(h k l)\right| と$ $\left|F_{\mathrm{C}}(\overline{h k l})\right|$ との違いが大きい50組以上のバイフット 対を選びだした。それらの $\left|F_{\mathrm{O}}(h k l)\right|-\left|F_{\mathrm{O}}(\overline{h k l})\right|$ と $\left|F_{\mathrm{C}}(h k l)\right|-\left|F_{\mathrm{C}}(\overline{h k l})\right|$ との相関の有無を検討したが, どのモテルの場合も相関はなかった。各モテルの $R$ 值は $\mathrm{P} 6_{3} / \mathrm{mmc}$ モテルのR值より低かったが，その 差は小さく，パラメー夕数を考慮すれば有意でな いと結論できた。以上から， $\mathrm{NaV}_{6} \mathrm{O}_{11}$ は対称心を 持つ空間群 $\mathrm{P} 6_{3} / \mathrm{mmc}$ に属すると判断した。 $\mathrm{SrV}_{6} \mathrm{O}_{11}$ の空間群も同様の手順で検討し, $\mathrm{NaV}_{6} \mathrm{O}_{11}$ と同じ $\mathrm{P}_{3} / \mathrm{mmc}$ に属すると判断した ${ }^{5)}$ 。

$\mathrm{NaV}_{6} \mathrm{O}_{11}, \mathrm{SrV}_{6} \mathrm{O}_{11}$ についてV(3)サイトの[001]方 向への変位の有無を検討したが, $R$ 值に有意差は見 られず，共に変位はおこらないと結論できた5)。

第1表から原子間距離を比較すると, $R$ ブロック の厚さ $R$, 面共有 $T(2)-T(2)$ サイト間距離, $T(3)$ サ イトの分裂距離 $T(3)-T(3)$, 化合物ごとの違いが 大きいことがわかる。 $A T_{6} \mathrm{O}_{11}$ 型に限ると, $\Delta R, \Delta$ $[T(2)-T(2)]$ は共に $\Delta[T(3)-T(3)]$ の $1 / 2$ にほほ等しい ことがわかる。一方，T(3)サイトが変位すると $T(3)$ とその上下にある2つのO(3) との距離は非等価とな るが, その短い方は $\mathrm{BaFe}_{12} \mathrm{O}_{19}$ も含めてほほ一定で

第 1 衣 $\mathrm{NaV}_{6} \mathrm{O}_{11}, \mathrm{SrV}_{6} \mathrm{O}_{11}$ および関連化合物の格子定数と原子間距離の比較

\begin{tabular}{|c|c|c|c|c|c|}
\hline & $\mathrm{NaV}_{6} \mathrm{O}_{11}{ }^{5)}$ & $\mathrm{SrV}_{6} \mathrm{O}_{11}{ }^{5)}$ & $\mathrm{BaTi}_{2} \mathrm{Fe}_{4} \mathrm{O}_{11}{ }^{7)}$ & $\mathrm{BaSn}_{2} \mathrm{Fe}_{4} \mathrm{O}_{11}{ }^{7)}$ & $\mathrm{BaFe}_{12} \mathrm{O}_{19}{ }^{8)}$ \\
\hline $\begin{array}{l}a \\
b\end{array}$ & $\begin{array}{r}5.7123(1) \\
13.0974(4)\end{array}$ & $\begin{array}{r}5.7716(1) \\
13.0793(5)\end{array}$ & $\begin{array}{r}5.8470(2) \\
13.6116(9)\end{array}$ & $\begin{array}{c}5.9624(5) \\
13.7468(14)\end{array}$ & $\begin{array}{r}5.893 \\
23.194\end{array}$ \\
\hline$R^{\mathbf{a}}$ & $6.5487(2)$ & $6.5397(3)$ & $6.8058(5)$ & $6.8734(7)$ & $6.573(3)$ \\
\hline$T(1)-O(1)$ & $1.9410(4) \times 4$ & $1.945(3) \times 4$ & $1.997(4) \times 4$ & $2.010(3) \times 4$ & $\begin{array}{l}1.928(5) \times 2 \\
2.106(4) \times 2\end{array}$ \\
\hline$T(1)-O(3)$ & $2.0327(6) \times 2$ & $2.029(6) \times 2$ & $1.997(4) \times 2$ & $2.052(3) \times 2$ & $\begin{array}{l}1.977(5) \times 1 \\
2.091(6) \times 1\end{array}$ \\
\hline$\overline{T(1)-0}$ & 1.9716 & 1.973 & 1.997 & 2.024 & 2.023 \\
\hline $\begin{array}{c}T(2)-O(1) \\
T(2)-O(2) \\
\frac{T(2)-O}{T}\end{array}$ & $\begin{array}{l}1.9024(3) \times 3 \\
2.0210(2) \times 3 \\
1.9617\end{array}$ & $\begin{array}{l}1.949(2) \times 3 \\
2.026(1) \times 3 \\
1.988\end{array}$ & $\begin{array}{l}1.933(7) \times 3 \\
2.105(8) \times 3 \\
2.019\end{array}$ & $\begin{array}{l}1.998(5) \times 3 \\
2.163(4) \times 3 \\
2.081\end{array}$ & $\begin{array}{l}1.975(8) \times 3 \\
2.060(7) \times 3 \\
2.018\end{array}$ \\
\hline $\begin{array}{l}T(3)-O(2) \\
T(3)-O(3)\end{array}$ & $\begin{array}{l}1.7869(6) \times 3 \\
2.086(1) \times 2\end{array}$ & $\begin{array}{l}1.832(6) \times 3 \\
2.11(1) \times 2\end{array}$ & $\begin{array}{l}1.867(5) \times 3 \\
2.098(14) \times 1 \\
2.583(14) \times 1\end{array}$ & $\begin{array}{l}1.907(5) \times 3 \\
2.044(10) \times 1 \\
2.603(10) \times 1\end{array}$ & $\begin{array}{l}1.886(10) \times 3 \\
2.170(11) \times 1 \\
2.472(11) \times 1\end{array}$ \\
\hline $\begin{array}{l}A-\mathrm{O}(1) \\
\frac{A-\mathrm{O}(2)}{A-\mathrm{O}}\end{array}$ & $\begin{array}{l}2.7436(5) \times 6 \\
2.8595(5) \times 6 \\
2.8016\end{array}$ & $\begin{array}{l}2.697(3) \times 6 \\
2.891(4) \times 6 \\
2.794\end{array}$ & $\begin{array}{l}2.828(4) \times 6 \\
2.928(4) \times 6 \\
2.878\end{array}$ & $\begin{array}{l}2.842(4) \times 6 \\
2.987(4) \times 6 \\
2.915\end{array}$ & $\begin{array}{l}2.865(6) \times 6 \\
2.952(1) \times 6 \\
2.909\end{array}$ \\
\hline $\begin{array}{l}T(2)-T(2) \\
T(3)-T(3)\end{array}$ & $\begin{array}{l}2.6840(4) \\
0.0\end{array}$ & $\begin{array}{l}2.721(3) \\
0.0\end{array}$ & $\begin{array}{l}2.904(22) \\
0.485(24)\end{array}$ & $\begin{array}{l}3.002(8) \\
0.559(17)\end{array}$ & $\begin{array}{l}2.778(1) \\
0.312(20)\end{array}$ \\
\hline $\begin{array}{c}\Delta R^{\mathrm{b}} \\
\Delta[T(2)-T(2)]^{\mathrm{b}} \\
\Delta[T(3)-T(3)]^{\mathrm{b}}\end{array}$ & $\begin{array}{l}0.0 \\
0.0 \\
0.0\end{array}$ & $\begin{array}{l}-0.0090 \\
0.37 \\
0.0\end{array}$ & $\begin{array}{l}0.2571 \\
0.220 \\
0.485\end{array}$ & $\begin{array}{l}0.3247 \\
0.318 \\
0.559\end{array}$ & $\begin{array}{l}0.024 \\
0.094 \\
0.312\end{array}$ \\
\hline
\end{tabular}




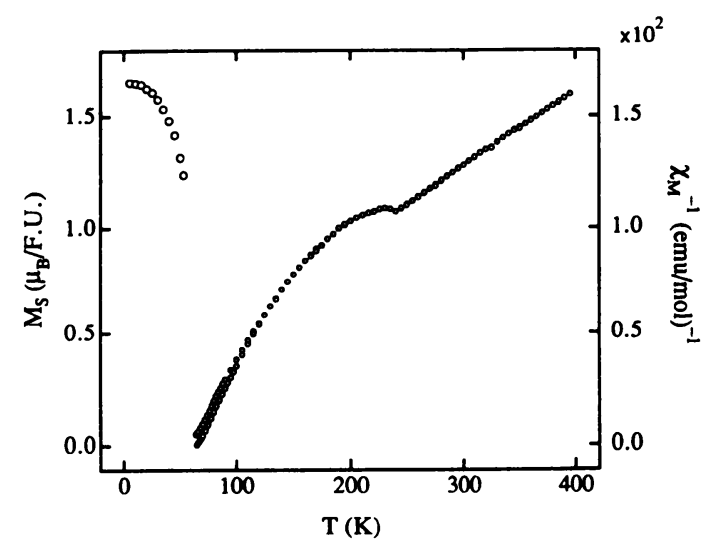

第2図 $\mathrm{NaV}_{6} \mathrm{O}_{11}$ の自発磁化(左)および磁化 率の逆数(右)の温度依存性 ${ }^{9)}$

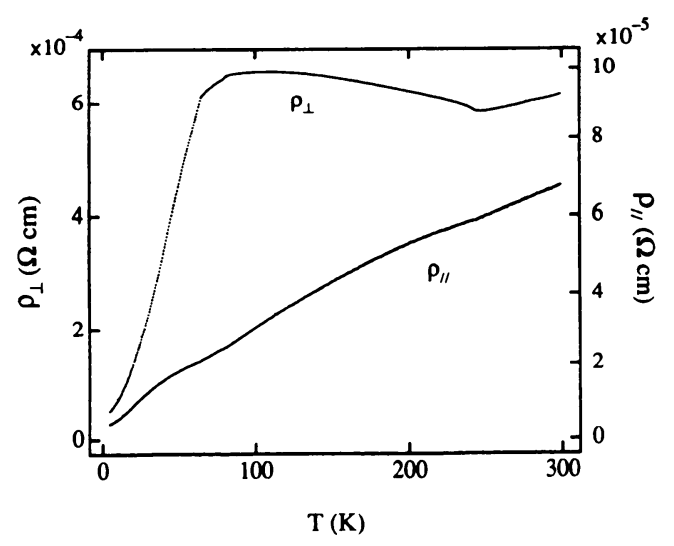

第3図 $\mathrm{NaV}_{6} \mathrm{O}_{11}$ の抵抗率の温度依存性9)

ある。すなわち，4種 $A T_{6} \mathrm{O}_{11}$ 型相におけるRと $T(2)-$ $T(2)$ 違いは，ほほT(3)サイトの変位のみに起因す る。また, $T(1)-O(1), O(3) 八$ 面体が成す[001]に垂 直な層とその上下に㜔接する $2 つ の T(2)$ 層とがつく る構造単位は，4種 $A T_{6} \mathrm{O}_{11}$ 型相で本質的に変わらな い。しかし $\mathrm{BaFe}_{12} \mathrm{O}_{19}$ ではこの議論は成立せず，上 記の構造単位は, $A T_{6} \mathrm{O}_{11}$ 型相と $\mathrm{BaFe}_{12} \mathrm{O}_{19}$ とに共通 しないことがわかる5゙。

\section{3 伝落度と磁性}

$\mathrm{NaV}_{6} \mathrm{O}_{11}$ 単結晶試料の磁化曲線を測定した。磁 場を[001]方向に印加した場合は，60K以下でヒス テリシスを示した。53K以下では，磁化 $\left(M_{||}\right)$は約 $5800 \mathrm{e} て ゙$ 飽和した後, 測定最大磁場 55kOeまで微増 する。一方，磁場を[001]に垂直方向に引加した場 合は, 35K以下で55kOeまで磁場に比例し, 飽和し ない。 $\mathrm{NaV}_{6} \mathrm{O}_{11}$ は, キュリー点が64.2Kの, [001]
を磁化容易軸とする一軸磁気異方性を示すことが 判明した。 $5 \mathrm{~K} て の$ 自発磁化は組成式当たり $1.7 \mu_{\mathrm{B}}$ であった(第2図) $)^{9)}$ 。

$\mathrm{NaV}_{6} \mathrm{O}_{11}$ の磁化率は $240 \mathrm{~K}$ 以上でワイス定数一 $81 \mathrm{~K}$ のュリー・ワイス則に従う。 $240 \mathrm{~K}$ 付近で磁 気異常が観測され, キュリー点付近の磁化率はワ イス定数66Kのキュリー・ワイス則に従う。240K 以上とキュリー点付近では, ワイス定数の符号が 逆転している(第2図) $)^{9)}$ 。

第3図に $\mathrm{NaV}_{6} \mathrm{O}_{11}$ 単結晶の[001] に垂直, 平行方 向の電気抵抗率 $\rho_{\perp}, \rho_{/ /}$の温度依存性を示す9)。 $\rho_{/ /}$ は全温度領域で金属的である。 $\rho_{\perp}$ は $64.2 \mathrm{~K}$ 以下で 金属的であるが， 64.2K 以上ではほほ一定值をと る。ただ 245Kに異常があり，それ以上では金属 的，それ以下では半導体的である。245Kの転移点 は磁化率の異常(240K)に対応している。64.2K以下 で $\rho_{\perp}$ の急激な減少は $\mathrm{Fe}, \mathrm{Co}, \mathrm{Ni}$ 等の金属磁性体 が示す異常抵抗を想起させる。64.2K以下では $\rho_{\perp}$, $\rho_{/ /}$共に金属的であることから, $\mathrm{NaV}_{6} \mathrm{O}_{11}$ は局在 $\mathrm{d}$ 電 子型のフェリ磁性ではなく, 遍歴電子弱強磁性と 予想される9)。

単結晶試料の測定から $\mathrm{SrV}_{6} \mathrm{O}_{11}$ は約70K以下で, [001] 磁化容易軸とする一軸磁気異方性を示し, 絶縁体になることが判明した。これは $\mathrm{NaV}_{6} \mathrm{O}_{11}$ の 64.2Kでの転移に対応するが，転移点以下での電気 伝導性は対照的である。 $\mathrm{SrV}_{6} \mathrm{O}_{11}$ は約70K以上では 常磁性半導体である。約320Kで抵抗率に異常が見 られ，それ以上の温度では磁化率がキュリー・ワ イス則に従う。これは $\mathrm{NaV}_{6} \mathrm{O}_{11}$ の245Kでの転移に 対応する10)。

\section{3. $\mathrm{SrT}_{x} \mathrm{~V}_{6-x} \mathrm{O}_{11}(T=\mathrm{Ti}, \mathrm{Cr}, \mathrm{Fe})$ の結晶構造}

$\mathrm{NaV}_{6} \mathrm{O}_{11}, \mathrm{SrV}_{6} \mathrm{O}_{11}$ でV $\mathrm{V}^{\mathrm{III}}$ と $\mathrm{V}^{\mathrm{IV}}$ がどのように分布 するのかについて実験的知見を得るために， VIII, $\mathrm{V}^{\mathrm{IV}}$ の $\mathrm{Ti}^{\mathrm{IV}}, \mathrm{Cr} \mathrm{III} ， \mathrm{Fe}^{\mathrm{III}}$ による置換を試み， $\mathrm{Ti}$, $\mathrm{Cr}, \mathrm{Fe}$ は特定のサイトに集中した分布をとるの か，無秩序な分布をとるのかについて検討した。

\section{1 合 成}

$\mathrm{SrV}_{6} \mathrm{O}_{11}$ ではVの置換は可能て, $\mathrm{Sr}_{x} \mathrm{~V}_{6-x} \mathrm{O}_{11}(T=$ $\mathrm{Ti}: 0<x \leq 1.5, T=\mathrm{Cr}: 0<x \leq 1.0, T=\mathrm{Fe}: 0<x \leq$ 1.4)が得られた ${ }^{4)}$ 。 $\mathrm{NaT}_{x} \mathrm{~V}_{6-x} \mathrm{O}_{11}$ は得られず，かわり にマグネトプランバイト型の $\mathrm{NaFe}_{3} \mathrm{~V}_{9} \mathrm{O}_{19}{ }^{11)}$ が見い だされた。 
第2表 $\operatorname{Sr}_{x} \mathrm{~V}_{6-x} \mathrm{O}_{11}$ の各サイトにおけるTイオンの占有率4)

\begin{tabular}{lllll}
\hline 占有率 & $\mathrm{SrTiV}_{5} \mathrm{O}_{11}$ & $\mathrm{SrTi}_{1.5} \mathrm{~V}_{4.5} \mathrm{O}_{11}$ & $\mathrm{SrCrV}_{5} \mathrm{O}_{11}$ & $\mathrm{SrFeV}_{5} \mathrm{O}_{11}$ \\
\hline$g(T(1))$ & $0.12(2)$ & $0.13(2)$ & $0.15(1)$ & 0.0 \\
$g(T(2))$ & $0.24(3)$ & $0.39(3)$ & $0.23(2)$ & $0.238(4)$ \\
$g(T(3))$ & $0.16(7)$ & $0.35(9)$ & $0.07(6)$ & $0.564(8)$ \\
\hline
\end{tabular}

\section{2 枌末中性子回折法による置換サイトの決定}

$\mathrm{SrTiV}_{5} \mathrm{O}_{11}, \operatorname{SrTi}_{1.5} \mathrm{~V}_{4.5} \mathrm{O}_{11}, \operatorname{SrCrV}_{5} \mathrm{O}_{11}$, $\mathrm{SrFeV}_{5} \mathrm{O}_{11}$ の結晶構造を, 高エネルギー物理学研究 所の HRP ${ }^{12)}$ で得られた粉末中性子回折データを用 いて，RIETAN ${ }^{13)}$ で決定した4)。Vによる中性子の 散乱はスピン非干涉性散乱が大部分であり，干涉 性散乱(回折)にはほとんど寄与しない(14)。従って, $\mathrm{V}$ を他の元素で置換すると, 他の元素のみが中性子 回折によって“見える”ことになる。これを利用 してVと Ti， Cr， Feとの判別に成功した。Tイオ ンの分布を第2表に示す。

各 $\mathrm{Sr}_{x} \mathrm{~V}_{6-\mathrm{x}} \mathrm{O}_{11}$ についてマーテルングエネルギー を計算した結果， $T(1)$ サイトは+3価のイオンを好 み，T(2)サイトは+4価のイオンを好むこと，T(3) サイトは基本的に +3 価のイオンを好むことがわ かった4)。サイトプリファレンスをみると， V ${ }^{\mathrm{III}}$, $\mathrm{Cr}^{\mathrm{III}}$ が八面体型6配位以外の配位様式をとる例は知 られていない。特にC $\mathrm{Cr}^{\mathrm{III}}$ はd $\mathrm{d}^{3}$ あ゙り, 結晶場によ り八面体型6配位のとき電子状態が安定化される。 $\mathrm{Ti}^{\mathrm{IV}}, \mathrm{V}^{\mathrm{IV}}$ は共に5配位を取りうる。一方 $\mathrm{Fe}^{\mathrm{III}}$ は $\mathrm{d}^{3}$ であり，四面体型4配位もとりやすい。三方両錐型 5配位はある意味で四面体型4配位に近いことを考 慮すれば，以上から，Tiは $T(2) に, C r は T(1) に ，$ Fe は $T(3)$ に片寄った分布をとることが期待され

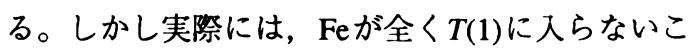
と，CrがT(3)にほとんど入らないことを除けば， 各Tイオンは特定のサイトに片寄らず，3種サイト に無秩序に分布している (第 2 表) $)^{4}$ 。以上から $\mathrm{SrV}_{6} \mathrm{O}_{11}, \mathrm{SrT}_{x} \mathrm{~V}_{6-x} \mathrm{O}_{11}$ では, +3価と+4価のカチオ ンはかなり無秩序に分布していることが示され, $\mathrm{d}$ 電子が非局在状態にあることが強く示唆される。

\section{$3.3 \mathrm{NaFe}_{3} \mathrm{~V}_{9} \mathrm{O}_{19}$ の伝等度と磁性}

焼結体試料の測定から, $\mathrm{NaFe}_{3} \mathrm{~V}_{9} \mathrm{O}_{19}$ は約 $240 \mathrm{~K}$ 以 下で自発磁化を示すことがわかった。磁化容易軸 は $\mathrm{BaFe}_{12} \mathrm{O}_{19}$ と同様 $[001]$ に平行である ${ }^{11)}$ 。磁気転移 点は圧力を加えると上昇する15)。抵抗率の温度依 存性は半導体的であり, 磁気転移点付近に異常は
見られなかった11)。しかし焼結体の抵抗率は粒界 の影響等によりバルクを反映しないことが多く, 単結晶試料の測定が望まれる。

\section{4.おわりに}

3価 4価混合原子価領域のバナジウム複合酸化 物は比較的少ない。 $A \mathrm{~V}_{6} \mathrm{O}_{11}$ 系を除けばスピネル 型, ペロブスカイト型等の一般的な結晶構造を持 つ系にほほ限られる。これは, 酸素分圧による V の酸化数の制御が難しいこと，今まで自発磁化を 示す系が知られておらす, 磁性に対する興味が薄 かったこと等から，探索研究が少なかったためと 思われる。1節で述べたように，バナジウムは多様 な結晶構造の酸化物をつくる可能性を秘めてい る。今後も新化合物の出現を期待したい。

磁気秩序を担いうる元素としてバナジウム以外 含まない物質が自発磁化を示す例は今まで知られ ておらず, $A \mathrm{~V}_{6} \mathrm{O}_{11}$ 系の磁性は興味深い。同じ 3 価 ４価混合原子価領域のマグネリ相 (金属一絶縁体 モット転移) ${ }^{16)}$, 正スピネル型 $\mathrm{LiV}_{2} \mathrm{O}_{4}$ (金属伝導性, キュリー・ワイス常磁性) ${ }^{17)}$ とは全く異なる性質を 示す。 $A \mathrm{~V}_{6} \mathrm{O}_{11}$ 系の磁気構造の解明は意義深い。

$\mathrm{NaFe}_{3} \mathrm{~V}_{9} \mathrm{O}_{19}$ の V は混合原子価状態にある。最 近, 日本原子力研究所の $\mathrm{HRPD}^{18)}$ で得られた粉末中 性子回折データと, 粉末 X 線回折データから, RIETAN $^{13)}$ により結晶構造が決定された ${ }^{19)}$ 。遷移金 属イオンの分布は $\operatorname{Sr} T_{x} \mathrm{~V}_{6-x} \mathrm{O}_{11}$ 系と同様, 基本的に 無秩序であることが判明し, 非局在 $\mathrm{d}$ 電子の存在が 示唆された。

最後に御指導, 御援助頂いた, 無機材質研究所 の加藤克夫氏, 室町英治氏, 泉富士夫氏, 磯部光 正氏, 内田吉茂氏, 松井良夫氏, 竹川俊二氏, 田 村修蔵氏, 今野重久氏, 和田壽璋氏, 佐藤晃氏, 小須田幸助氏，筑波大学物質工学系の浅野肇氏, 神山崇氏, ならびに日本原子力研究所東海研究所 の船橋達氏, 森井幸生氏, 皆川宣明氏, 下条豊氏 に感謝致します。 


\section{文献}

1) N. F. Mott : Metal Insulator Transitions (Taylor \& Francis,1974).

2) A. Fujimori and F. Minami : Phys. Rev. B30, 957 (1984).

3) M. E. de Roy, J. P. Besse, R. Chevalier and M. Gasperin : J. Solid State Chem. 67, 185 (1987).

4) Y. Kanke, F. Izumi, E. Takayama-Muromachi, K. Kato, T. Kamiyama and H. Asano : J. Solid State Chem. 92, 261 (1991).

5) Y. Kanke, K. Kato, E. Takayama-Muromachi and M. Isobe : Acta Cryst. C48, 1376 (1992).

6) Y. Kanke, E. Takayama-Muromachi, K. Kato and Y. Matsui : J. Solid State Chem. 89, 130 (1990).

7) M. C. Cadée and D. J. W. Ijdo : J.Solid State Chem. 52, 302 (1984).

8) W. D. Townes, J. H. Fang and A. J. Perrotta : Z. Krist. 125, 437 (1967).

9) Y. Uchida, Y. Kanke, E. Takayama-Muromachi and K. Kato : J. Phys. Soc. Jpn. 60, 2530 (1991).

10) Y. Uchida, Y. Kanke and Y. Onoda :
Proceedings of the 6th International Conference on Ferrites, 722 (1992).

11) Y. Kanke, E. Takayama-Muromachi, Y. Uchida, K. Kato and S. Takekawa : J. Solid State Chem. 95, 438 (1991).

12) N. Watanabe, H. Asano, H. Iwasa, S. Satoh, H. Murata, K. Karahashi, S. Tomoyoshi, F. Izumi and K. Inoue : Jpn. J. Appl. Phys. 26, 1164 (1987).

13) F. Izumi, H. Asano, H. Murata and N. Watanabe : J. Appl. Cryst. 20, 411 (1987).

14) V. F. Sears, Neutron, Scattering, Part A. Methods of Experimental Physics 23, K. Sköld and D. L. Price : Eds. (Academic Press, 1986).

15) S. Tamura and Y. Kanke : J. Phys. Soc. Jpn. 60, 4386 (1991).

16) S. Kachi, K. Kosuge and H. Okinaka : J. Solid State Chem. 6, 258 (1973).

17) D. B. Rogers, J. L. Gillson and I. E. Gier : Solid State Commun. 5, 263 (1967).

18）森井幸生：日本結晶学会誌 34, 62 (1992).

19) Y. Kanke, F. Izumi, Y. Morii, S. Funahashi and K. Kato : J. Solid State Chem., in the press. 